\title{
Pengaruh Pelarut dan Ukuran Template Terhadap Struktur $\mathrm{TiO}_{2}$ (Effect of solvent and template size on the structure $\mathrm{TIO}_{2}$ )
}

\author{
Hermawan. D. C., Haryati. T., Supriyanto. E. \\ Jurusan Kimia, Fakultas Matematika dan Ilmu Pengetahuan Alam, Universitas Jember (UNEJ) \\ Jln. Kalimantan 37, Jember 68121 \\ E-mail: tanti_chems@yahoo.com
}

\begin{abstract}
Abstrak
Sintesis titanium oksida $\left(\mathrm{TiO}_{2}\right)$ telah dilakukan pada penelitian ini menggunakan metode sol gel. Titanium isopropoksida

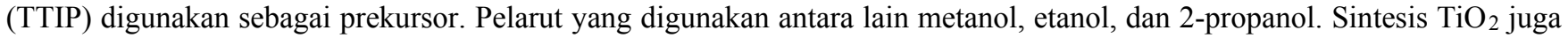
memakai polietilen glikol (PEG) sebagai molekul template. Variasi yang digunakan adalah variasi pelarut dan berat molekul template. Hasil analisa XRD untuk variasi pelarut menunjukkan bahwa pelarut metanol menghasilkan ukuran kristal yang lebih kecil dibandingkan dengan etanol dan 2-propanol yaitu sebesar 137,50 nm.
\end{abstract}

Kata Kunci: Pelarut, Polietilen glikol, Sol Gel, $\mathrm{TiO}_{2}$.

\section{Abstract}

Synthesis of titanium oxide (TiO2) has been done in this study using a sol-gel method. Titanium isopropoxide (TTIP) is used as a precursor. Solvents used include methanol, ethanol and 2-propanol. In the synthesis used Polyethylene glycol as template molecule. Variations used is a variation of the solvent and the molecular weight of the template. Variations used is solvent and template molecular weight (PEG). The results of XRD analysis to show that the variation of solvent methanol produces crystal and particle size smaller than ethanol and 2-propanol in the amount of $137.50 \mathrm{~nm}$.

Keywords: Solvents, Polyethylene glycol, Sol Gel, $\mathrm{TiO}_{2}$.

\section{PENDAHULUAN}

Titanium oksida $\left(\mathrm{TiO}_{2}\right)$ adalah material fotoanoda yang sering digunakan dalam DSSC [1]. Hal ini dikarenakan Energi bandgap yang dimiliki $\mathrm{TiO}_{2}$ sangat besar, yaitu 3,2 $\mathrm{eV}$ untuk fase anatase dan 3,0 eV untuk fase rutile [2]. Kinerja DSSC sangat dipengaruhi oleh morfologi dari $\mathrm{TiO}_{2}$ yang digunakan sebagai material fotoanoda. Luas permukaan yang tinggi merupakan salah satu karakteristik dari material nanopartikel [3]. Sintesis $\mathrm{TiO}_{2}$ menggunakan template telah dilakukan oleh Sasti (2011), dengan metode hidrotermal. Pada penelitian tersebut etanol digunakan sebagai pelarut dan polietilen glikol 1000 dipakai sebagai template. Hasil karakterisasi yang diperoleh merupakan $\mathrm{TiO}_{2}$ anatase dengan ukuran 50-90 nm. Ridwan et al (2015), juga telah melakukan sintesis $\mathrm{TiO}_{2}-\mathrm{SiO}_{2}$ dengan menggunakan sol-gel sebagai metode sintesis. Variasi pelarut yang digunakan pada penelitian tersebut adalah metanol, 1- propanol, dan 2-propanol dihasilkan ukuran partikel sebesar 25,64 nm untuk 1- propanol dan 27,15 nm untuk 2-propanol. Pada penelitian ini dilakukan sintesis lapis tipis $\mathrm{TiO}_{2}$ dengan menggunakan polietilen glikol sebagai template memakai metode sol-gel. Parameter yang digunakan dalam penelitian ini ialah variasi penggunaan pelarut dan variasi berat molekul template polietilen glikol(PEG). Karakterisasi yang digunakan pada penelitian ini adalah XRD (X-ray Difraction) untuk mengetahui struktur kristal, kristalinitas dari sampel $\mathrm{TiO}_{2}$ \& SEM (Scanning Electrons Microscopy) untuk mengetahui morfologi dari sampel $\mathrm{TiO}_{2}$ serta FTIR (Fourier Transform Infrared) untuk mengetahui keberadaan gugus fungsi polietilen glikol dari sampel sebelum dan sesudah proses annealing pada $\mathrm{TiO}_{2}$.

\section{METODE PENELITIAN}

Prekursor yang digunakan adalah TTIP. TTIP sebanyak $910 \mu \mathrm{L}$ dimasukkan ke dalam etanol $19 \mathrm{~mL}$. Selanjutnya dilakukan proses pengadukan menggunakan stirer magnetik selama 20 menit dengan menambahkan tetes demi tetes $\mathrm{HCl}$ pH 1 sebanyak $720 \mu \mathrm{L}$. Setelah itu dilakukan penambahan PEG 400 sebanyak $60 \mu \mathrm{L}$ ke dalam larutan sol $\mathrm{Ti}(\mathrm{OH}) 4$. Pengadukan dilakukan kembali selama 30 menit memakai stirer magnetik. Sintesis selanjutnya dilakukan dengan prosedur yang sama namun menggunakan pelarut berbeda (2-propanol dan metanol) dan polietilon glikol dengan berat molekul berbeda (PEG 600 sebanyak $90 \mu \mathrm{L}$ ).

Kaca preparat disiapkan dengan cara dipotong dengan ukuran $(2 \times 2) \mathrm{cm}$. Kemudian dicuci menggunakan aseton, etanol, dan aqua bidestilat masing- masing selama 5 menit, lalu dikeringkan. Kaca preparat selanjutnya diberi double tape dan ditempelkan pada alat spin-coater lalu ditetesi dengan sol titanol $(\mathrm{TiOH})_{4}$ pada permukaannya sebanyak 10 tetes. Kemudian didiamkan selama \pm 40 detik, selanjutnya diputar selama \pm 20 detik dan proses terakhir dilakukan pendiaman selama \pm 5 menit. Prosedur pelapisan di lakukan kembali sebanyak 10 kali. kemudian dilakukan proses aging (pematangan) selama 24 jam. Setelah itu, sebagian dari sampel di annealing pada suhu $600^{\circ} \mathrm{C}$ selama 3 jam menggunakan furnace. Sebagian lagi diuji menggunakan FTIR. Lapisan tipis yang dihasilkan setelah proses annealing dikarakterisasi menggunakan XRD dan FTIR. 


\section{HASIL PENELITIAN}

Sintesis nanopartikel $\mathrm{TiO}_{2}$ telah berhasil dilakukan menggunakan metode sol-gel. Sintesis ini menggunakan prekursor titanium isopropoksida dan metode pelapisan menggunakan metode spin coating. Templating agent juga ditambahkan dalam sintesis ini dengan tujuan untuk mengontrol struktur $\mathrm{TiO}_{2}$. Polietilen glikol merupakan salah satu templating agent yang sebagian besar digunakan. Gambar 1 menunjukkan reaksi yang terjadi antara polietilen glikol dengan $\mathrm{Ti}(\mathrm{OH})_{4}$ :

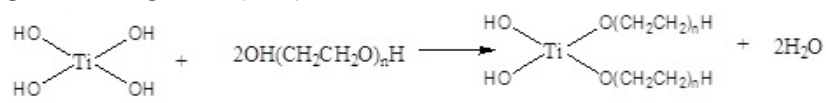

Gambar 1. Reaksi Ti(OH)4 dengan polietilen glikol

FTIR (Fourier Transform Infra Red) merupakan salah satu instrumen yang digunakan untuk menentukan gugus fungsi dari suatu senyawa. Polietilen glikol adalah suatu polimer dengan etilen glikol sebagai monomernya. Rumus molekul polietilen glikol dituliskan sebagai berikut :

$\mathrm{H}-\left(\mathrm{OCH}_{2}-\mathrm{O}-\mathrm{CH}_{2}-\right)_{n}-\mathrm{OH}$

Polietilen glikol memiliki gugus fungsi eter dan alkohol. Oleh karena itu dilakukan uji FTIR untuk menentukan keberadaannya pada sampel sebelum dan sesudah proses annealing. Hasil analisis FTIR dapat dilihat pada gambar 2.

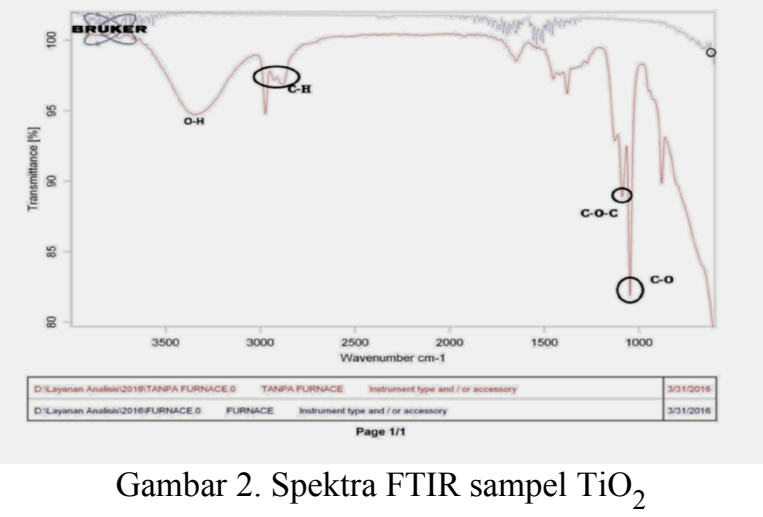

Gambar 2 menjelaskan bahwa sebelum proses annealing, polietilen glikol yang digunakan sebagai template masih terdapat pada sampel. Hal ini terlihat dari hasil FTIR yang memiliki kemiripan dengan standart ISU MatE453/MSE 553. Adanya serapan C-O-C pada rentang (1050-1150) $\mathrm{cm}^{-1}$ yang merupakan karakteristik untuk gugus eter. serapan $\mathrm{O}-\mathrm{H}$ pada rentang $(3200-3600) \mathrm{cm}^{-1}$ karakteristik untuk gugus hidroksil. C-H untuk gugus alkana pada serapan $(2850-2960) \mathrm{cm}^{-1}$ dan serapan C-O alkohol pada rentang (1000-1260) $\mathrm{cm}^{-1}$.

Spektra IR yang ditunjukkan gambar 2 juga menjelaskan bahwa polietilen glikol setelah proses annealing telah menghilang. Hal ini dapat dilihat dari tidak adanya serapan C-O-C pada rentang (1050-1150) $\mathrm{cm}^{-1}, \mathrm{C}-\mathrm{O}$ pada $(1000-1260) \mathrm{cm}^{-1}$, dan $\mathrm{C}-\mathrm{H}$ pada $(2850-2960) \mathrm{cm}^{-1}$. Munculnya serapan pada panjang gelombang $665 \mathrm{~cm}^{-1}$ dimungkinkan merupakan spektrum inframerah untuk titanium dioksida anatase.

Sintesis menggunakan metode sol gel memiliki beberapa faktor yang dapat memrpengaruhi hasil sintesis, diantaranya ialah pemilihan pelarut dan template. Oleh karena itu, sintesis dengan menggunakan variasi pelarut dan template dilakukan. Pelarut yang digunakan adalah metanol, etanol dan 2-propanol. Sedangkan untuk template yang digunakan ialah PEG 400 dan 600. Hasil analisis XRD untuk variasi pelarut dapat dilihat pada gambar 3 dan 4.

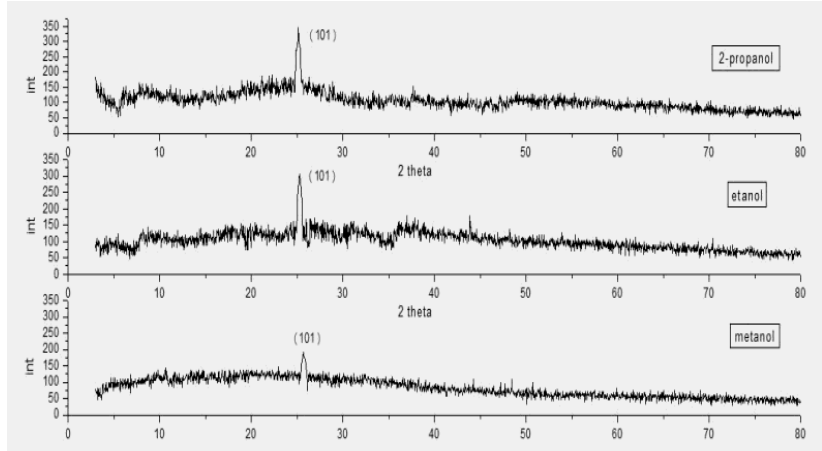

Gambar 3. Difraktogram variasi pelarut dengan PEG 600

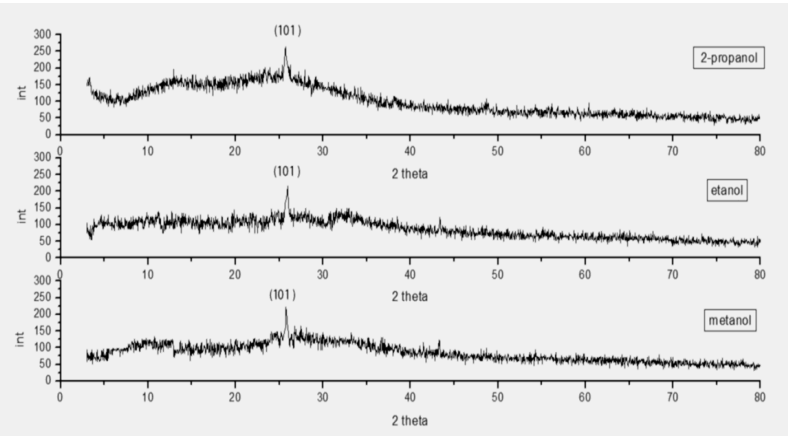

Gambar 4. Difraktogram variasi pelarut dengan PEG 400

Gambar 3 dan 4 menunjukkan bahwa sintesis $\mathrm{TiO}_{2}$ telah berhasil dilakukan. Hal tersebut dapat dilihat dari difraktogram yang didapatkan dari analisis menggunakan XRD setelah dicocokkan dengan standard $\mathrm{TiO}_{2}$ anatase pada JCPDS 211272. Bidang (101) pada standard $\mathrm{TiO}_{2}$ anatase muncul pada sudut $2 \theta=25,281$. Difraktogram sampel pada gambar 3 dan 4 juga muncul puncak khusus untuk $\mathrm{TiO}_{2}$ anatase yaitu pada sudut $2 \theta$ sekitar 25 . Ukuran kristal yang diperoleh dari variasi pelarut dapat dilihat pada tabel 1 dan 2 .

Tabel 1. Data difraktogram dan ukuran $\mathrm{TiO}_{2}$ variasi pelarut dengan PEG 400

\begin{tabular}{cccccc}
\hline Sampel & $2 \theta$ & $\begin{array}{c}\text { Bidang } \\
\text { difraksi }\end{array}$ & $\begin{array}{c}\text { Intensita } \\
\text { s }\end{array}$ & FWHM & $\mathrm{d}(\mathrm{nm})$ \\
\hline metanol & 25.76 & 101 & 222 & 0.14 & 119.33 \\
\hline etanol & 25.96 & 101 & 216 & 0.1 & 172 \\
\hline 2-propanol & 25.7 & 101 & 272 & 0.06 & 276.04
\end{tabular}

Tabel 2. Data difraktogram dan ukuran $\mathrm{TiO}_{2}$ variasi pelarut dengan PEG 600

\begin{tabular}{cccccc}
\hline Sampel & $2 \theta$ & $\begin{array}{c}\text { Bidang } \\
\text { difraksi }\end{array}$ & Intensitas & FWHM & $\mathrm{d}(\mathrm{nm})$ \\
\hline metanol & 25.7 & 101 & 196 & 0.12 & 137.5 \\
\hline etanol & 25.3 & 101 & 310 & 0.1 & 159.5 \\
\hline 2-propanol & 25.12 & 101 & 346 & 0.06 & 198.57 \\
\hline
\end{tabular}


Berdasarkan tabel 1 dan 2, dapat menjelaskan bahwa pelarut yang dipakai berpengaruh terhadap ukuran $\mathrm{TiO}_{2}$ yang disintesis. Pelarut metanol menghasilkan ukuran kristal yang lebih kecil dibandingkan dengan pelarut etanol maupun pelarut 2- propanol. Hal ini sesuai dengan literatur dimana perbedaan jenis pelarut berdampak pada proses hidrolisis. Semakin polar pelarut yang digunakan menyebabkan proses hidrolisis semakin mudah karena ikatan hidrogen antara prekursor dengan pelarut lebih mudah terjadi [5]. Selain itu, Selain itu pelarut yang polar akan lebih menstabilkan gugus titanol, dengan semakin banyak inti yang stabil maka reaksi kondensasi akan tersebar ke seluruh inti sehingga ukuran kristal yang terbentuk semakin kecil [6].

Metanol memiliki rantai $\mathrm{C}$ yang lebih pendek dibandingkan dengan etanol dan 2-propanol sehingga metanol memiliki tingkat kepolaran yang lebih besar dibandingkan dengan kedua pelarut lainnya. Sebaliknya untuk 2-propanol memiliki tingkat kepolaran yang paling rendah. Hal ini selain karena memiliki jumlah rantai $\mathrm{C}$ yang lebih besar, 2-propanol merupakan alkohol sekunder yang memiliki halangan sterik yang lebih besar dibandingkan alkohol primer. Oleh karena itu 2- propanol lebih sulit untuk berikatan hidrogen.

Template atau cetakan dalam sintesis material anorganik juga merupakan faktor yang dapat berpengaruh. Hal ini dikarenakan dapat mengontrol ukuran dari produk yang dihasilkan. Template yang digunakan dalam penelitian ini adalah Polietilen glikol (PEG) 400 dan 600. Hasil analisis XRD Variasi PEG ditunjukkan oleh gambar 5.

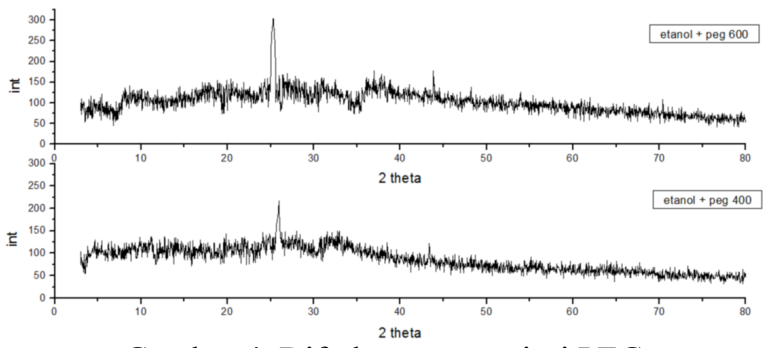

Gambar 4. Difraktogram variasi PEG

Gambar 5 menjelaskan bahwa hasil analisis XRD dari kedua macam $\mathrm{TiO}_{2}$ dengan Pelarut etanol + peg 400 dan pelarut etanol + peg 600 memiliki kemiripan yang hampir sama. Namun, hasil yang memiliki ukuran partikel lebih kecil tidak dapat ditentukan menggunakan XRD. Hal ini dikarenakan yang ditentukan dalam XRD merupakan ukuran kristal material berdasarkan pelebaran puncak difraksi yang muncul, bukan ukuran partikel [7].

\section{KESIMPULAN}

Pelarut yang digunakan dalam sintesis dapat mempengaruhi terhadap produk yang dihasilkan. Semakin polar pelarut yang digunakan maka semakin kecil ukuran yang diperoleh. Hasil XRD menunjukkan bahwa pelarut metanol menghasilkani ukuran kristal paling kecil dibandingkan etanol dan 2-propanol yaitu sebesar 137,5 $\mathrm{nm}$. Berat molekul template berpengaruh terhadap morfologi $\mathrm{TiO}_{2}$ yang dihasilkan. Semakin besar berat molekul yang digunakan akan menghasilkan produk dengan ukuran yang lebih besar juga. Perlu dilakukan sintesis dengan parameter lain dalam metode sol gel agar didapatkan material dengan ukuran dibawah $100 \mathrm{~nm}$.

\section{DAFTAR PUSTAKA}

[1] Phani, Tulloch, Vittorio, \& Skyrabin. 2001. Titania solar cells: new photovoltaic technology. Renewable Energy. Vol. 22(1): 303-309

[2] Arora, Doty, Yuan, Boyle, Petras, Rabatic, Paunesku \& Woloschak. 2010. Titanium Dioxide Nanocomposites. Nanomaterials for the Life Sciences. Vol.8(1): 1- 52

[3] Abdullah, M. 2008. Pengantar Nanosains. Bandung: ITB

[4] Sasti, H. T. 2011. "Studi Preparasi dan Karakterisasi Titanium Dioksida Mesopori”.Tidak Diterbitkan. Skripsi. Depok: Universitas Indonesia

[5] Ridwan, A., \& Wahyuni, S. 2015. Pengaruh Pelarut Terhadap Karakteristik Nano TiO2 - SiO2 Sebagai Penambah Self-Cleaning Cat Akrilik. Indonesian journal of Chemical Science. Vol. 4 (2): 1-6

[6] Schubert, U., \& Husing, N. 2005. Synthesis of Inorganic Material. Second, Revised and Updated Edition. Weinheim: Wiley-VCH Chaharmahali. 2012. "The Effect of $\mathrm{TiO} 2$ Nanoparticles on the Surface Chemistry, Structure and Fouling Performance of Polymeric Membranes". Tidak Diterbitkan. Thesis. Sydney: University of New South Wales.

[7] Abdullah, M. 2008. Pengantar Nanosains. Bandung: ITB. 